polyps. There is simply a fleshy tube with a mouth at the top, and a few small rounded prominences in place of tentacles, four of them sometimes the largest.

Arachnopora. New Genus.

Zoothome parasitic spreading like a small thin web over other corals.

\title{
Arachnopora aRgentea. n. $\mathbf{s}$.
}

Zoothome spreading in a small extremely thin web, silvery white, and in parts quite transparent, which are sparsely covered with small silvery granules. The calices are all small very slightly raised, rounded, on which septa protrude as three or six broadly triangular teeth; calices irregular, but with a tendency to a quincuncial arrangement. Length of zoothome 7, breadth 3 mil. Calices like minute dots, barely discernable to the unassisted eye.

In this species the substance of the zoothome seems a quite transparent membrance, on which there is generally a very close arrangement of small silvery granules. It occurs parasitic on corals, filling up half of the calice and spreading from opposite septa just like a spider's web. It also spreads over the sides of the costæ, where it appears just like a snail's track on which some very fine white dust had been sparsely scattered. There are no calices on the outside.

On a New Species of Psammoneris.

By the Rev. J. E. Tenison-Woods, F.G.S., F.L.S., Corr. Mem. Linn. Soc. N. S. W.

Plate $I$.

In 1848, Messrs. M. Edwards and J. Haime published in the Annales des Sciences Naturelles a definition of a new genus named Heterocyathus, which was referred to the second section of the Turbinolian family of corals. The genus thus established was meant to include simple cylindrical corals with a broad attachment always to shells which the base often enclosed, with 
conspicuous ribs, circular calice, an essential columella, exsert thick granular septa, and lobed pali. There were only two species in this genus, and one dependant upon a single specimen. They were always fixed upon a trochoid shell, which the tissue of the coral almost completely closed round in the course of its growth, and the only sign of its presence was the circular aperture which was always left for the molluse thus imprisoned. Subsequently Mons. M. Edwards discovered that one of the species, in spite of its pali and sub-entire septa which closely resembled the type of the genus in which it was placed, possessed synapticulæ, and should be separated, and placed in a distant family, the Fungidce. Here, however, it was also out of place, because no other genns of the family possesses pali. But the pali themselves are doubtful. They are lobed, and so are the septa, and indeed hardly distinguishable from them. In $1850 \mathrm{Mr}$. J. E. Gray added what he considered a third species to the genus. This was Heterocyathus hemisphericus, described in the Annals of Nat. Hist for 1850 (Second Series, Vol. 5, p. 410.) It was brought from the China Seas, and was thus described:-Corallum extremely short, four complete cycles; septa unequal, primaries very thick, especially near the columella, the next in extent are the fourth orcier, then the secondaries, then the fifth order, then the tertiaries, which are smaller than all the others, all very close, but little raised, and the border feebly arched. The two latter species have been erected into two genera. One Psammoseris, which is thus characterised: Corallum of trifling height, fixed on a shell which it completely encloses, except at the peristome; wall thick, bare, strongly granular, and scarcely striate beneath; columella papillary, septa scarcely prominent, thickly covered with very projecting granules, penultimate cycle more developed than the last, and approaching each other before the last. I confess that this description does not appear very clear. The words in French are as follows :"Celles (cloisons) de l'avant dernier cycle beaucoup plus développées que celles du dernier et rapprochées entre elles au-devant de ces dernieres.' It would seem as if the third cycle was larger than 
the fourth, but this is exactly contrary to the description of the type species, Gray's Heterocyathus hemisphericus, of which it is especially stated that the tertiaries are the smallest. If the orders were meant the description would be still more obscure.

The species I have to bring before the notice of the Society appears to me to be one that should be referred to Psammoseris. It is, however, very peculiarly distinguished by having the uniois of the fourth and fifth orders in front of the third, and the thickened lobate mass thus resulting unites again on each side in front of the secondaries. It also has pseudo-pali in the lobes, which spring from the septa, but they are many in number, and in fact the septa alone would incline one to refer the species to the Astrangiacece. The union between the septa is effected by small processes like synapticulæ, but the granules themselves on the faces of the septa never seem to unite. The mode of junction and the inclination of the septa recalls Eupsammidce, but the wall is quite imperforate. There does not appear to be any other resemblance except the junction of the septa. There is the greatest difference between the various specimens in the thickness and granulation of the septa. Some are so thick and close that the granules almost touch, making the calicular fossa seem like a regularly paved cavity; others are thin, wavy, and scarcely granular, having the rough fossa very conspicuously uneven from the lobes of the septa.

\section{Psammoseris Crlicioides. n. $\mathrm{s}$.}

Corallum in general fastened to the mouth of a turriculate shell (Mitra amanda, Reeve, M. hebes \&c., an unknown Terebra, and some shells, which are quite covered except at the aperture), base wider than calice, and more or less constricted between, and all the exterior irregularly covered with fine granules; calice irregularly circular, fossa deep and wide; septa exsert, in six systems of four cycles; primaries with the two fourth orders and secondaries with the two fifth projecting above the edge in closely adpressed sets of three septa, the higher orders diverge from the first and second to meet before the third, and the 
resulting tissue unites at once to the second, which forms thence a confused mass, sending up almost perpendicular lobes like pali, which are very granular; columella only a few inconspicuous papillæ at the base of the fossa; laminæ of nearly equal thickness, the primaries being free throughout, and only slightly thicker; costæ conspicuous and distinct, corresponding to the septa, and about equal for the three first orders, the fourth and fifth being equal, small, and in some specimens only represented by a line of granules; intercostal spaces about equal, rather deep and smoeth.

\section{Alt. 5, diam. 7. Princess Charlotte's Bay.}

There is a remarkable peculiarity in these corals, which is, that the granulations which cover the ribs sometimes extend a long way upon the spire of the shell on which they grow even far beyond other traces of the basal tissue.

\section{Explanation of Plate I.}

Fig. 1. Corallum attached to shell, magnified 2 diameters.

" 2. Corallum covering attached shell, magnified 2 diam.

"3. Calice of fig. 1 ; 3 diam.

"4. One system of costæ; 4 diam.

„5. One system of septa ; 4 diam.

\section{EXHIBITS.}

E. P. Ramsay, Esq., exhibited a very fine specimen of Osteoglossum Leichardtii (Barramundi), from the Dawson River, Queensland.

MONDAY, 25тн MARCH, 1878.

W. J. Stephens, Esq., M.A., President, in the Chair.

The Chairman introduced Captain Hutton, of the Otago Museum, New Zealand, to the meeting.

\section{MEMBERS ELECTED.}

E. Meyrick, Esq.; and C. Lentzner, Esq. 


\section{$2 \mathrm{BHL}$ Biodiversity Heritage Library}

Woods, Julian Tenison. 1878. "On a new species of Psammoseris." Proceedings of the Linnean Society of New South Wales 3, 8-11. https://doi.org/10.5962/bhl.part.22206.

View This Item Online: https://www.biodiversitylibrary.org/item/30232

DOI: https://doi.org/10.5962/bhl.part.22206

Permalink: https://www.biodiversitylibrary.org/partpdf/22206

\section{Holding Institution}

MBLWHOI Library

\section{Sponsored by}

MBLWHOI Library

\section{Copyright \& Reuse}

Copyright Status: NOT_IN_COPYRIGHT

This document was created from content at the Biodiversity Heritage Library, the world's largest open access digital library for biodiversity literature and archives. Visit BHL at https://www.biodiversitylibrary.org. 